\title{
Study on the Possibility of Subprime Crisis or Other Forms of Financial Crisis in China
}

\section{Rundong Wang}

Beijing New Oriental Foreign Language School at Yangzhou, Yangzhou, Jiangsu, China

Abstract. It has been 13 years since the subprime crisis happen in the USA. The America has regained its vitality it had lost from the crisis, but in China a new hyperpower, the real estate section seems to stage the same history, rising price and house buying frenzy, as America did. It is worth thinking about that whether the next subprime crisis or a similar financial crisis happen in China.

Keywords: Subprime Crisis; Financial Crisis; Similarity; Differences.

\section{Introduction}

This paper will divide the discussion into two parts-- the cause of America subprime crisis, the similarity and differences between Chinese and United States housing and financial system. Figure 1 shows the increase in house prices in the US before the crisis.

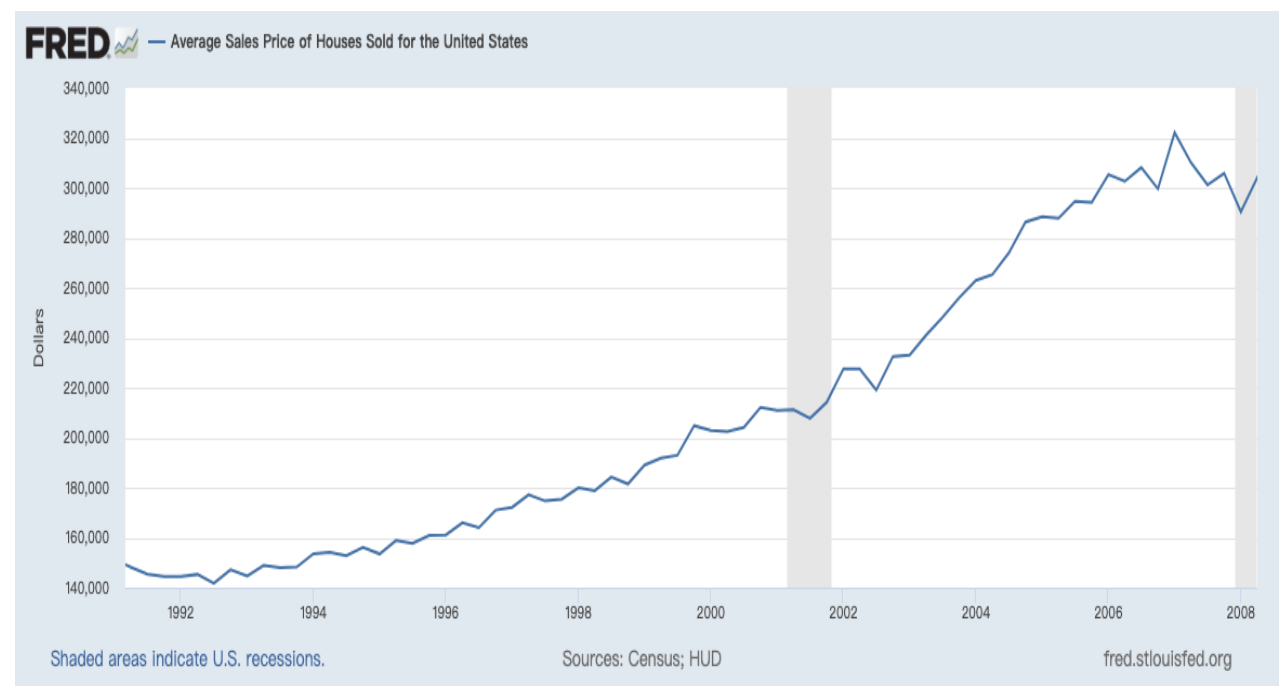

Figure 1. Average sales prices of houses sold in the United States (Sources: https://fred.stlouisfed.org/series/ASPUS)

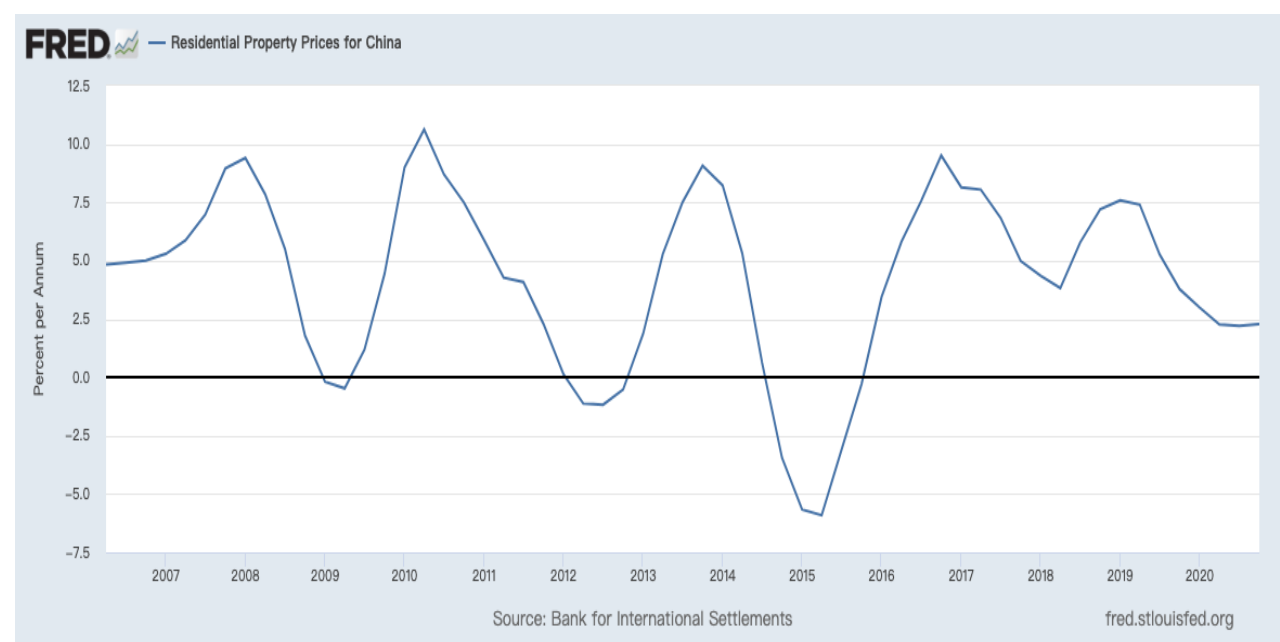

Figure 2. Residential property prices for China

(Sources: https://fred.stlouisfed.org/series/QCNR368BIS) 


\section{Causes of the US Subprime Crisis}

Till today, there are still debates about some causes of the subprime crisis, but certainly, some factors are generally recognized. Firstly, the risk in the whole financial system was built up too high, so in the end nobody can control it. At first, the banking industry regulated quite strict, so risk left banking sector and went to shadow banking sector to bypass regulations. Shadow bank, for example, like SIV, hedge fund. Hedge funds are actively managed investment pools whose managers use a wide range of strategies, often including buying with borrowed money and trading esoteric assets, in an effort to beat average investment returns for their clients. They are considered risky alternative investment choices. Hedge funds require a high minimum investment or net worth, excluding all but wealthy clients. (Barnier, 2021) At the same time, the investors were looking for the substitute to the US Treasuries. As a result, these demands create the new investment product such as CDOs and MBS. A mortgage-backed security (MBS) is an investment like a bond that is made up of a bundle of home loans bought from the banks that issued them and investors in MBS receive periodic payments like bond coupon payments (Kagan, 2021). A collateralized debt obligation (CDO) is a complex structured finance product that is backed by a pool of loans and other assets and sold to institutional investors (TARDI, 2021).

Since these products were created, the investors, home lenders, and investment banks gain the profit which is higher than ever. To expand their profit, they want to make more MBS and CDOs, but there are no more qualified house buyers in the market. Eventually, bankers figured out a way which is that they offered loans to these people who didn't have proof of income and did not require down payment. The lenders didn't not worry about mortgage default, since the house prices are always increasing. If the mortgage doesn't pay back on time, they just need to sell the houses and still can get profit.

\section{Estimated Size of the Global CDO Market*}

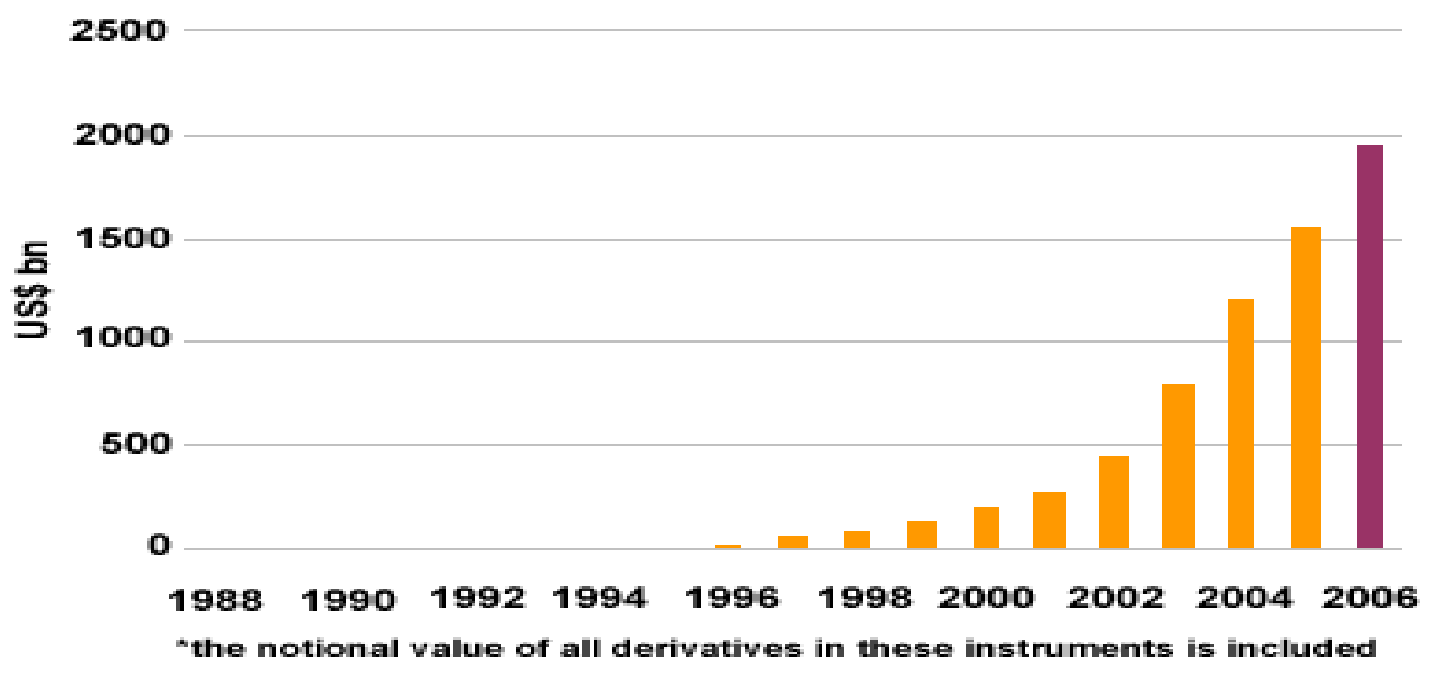

Figure 3. The size of global CDO market

(Source: https://www.celent.com/insights/893069741)

However, this situation didn't last forever, since more and more unqualified borrowers can't pay the bill on time. Then the bankers sold more and more houses on the market, and that means the supply becomes more. Then, the house prices went down. In the end, even the qualified house owners decided to not to pay the mortgage, since it doesn't make sense for them to repay a 500,000 dollars loans, while their house values only worth 250,000 dollars (Jarvis, 2012).

When the shock caused by the burst of housing bubble happened and the investment bank started to suffer, the investors started to drawback their money and triggered a run on the shadow bank system. 
After the fall of Lehman brother, the Reserve fund, a money market fund, for example, failed to keep its NAV per share above 1 dollar, which we called break the buck, because this fund had Lehman brothers' 785 short term loans and now these loans are worthless. Furthermore, although this is just a part of fund' s asset, this had already caused investors of the funds panic and made them to drawback their capital. Finally, the Reserve fund gone in the history and causes other chain reaction.

There's also a liquidity problem which contributes to the crisis. The banks will stop lending when they feel the market is not safe, which will cause the liquidity problems. For instance, If a bank has loan to pay during that time and it doesn't have cash right now on the account, it has to borrow money from other bank, but nobody would lend. So even this bank has high quality assets it will still go bankrupt. This is liquidity problemgover

\section{China and United States: Similarities and Differences}

Go back to Chinese case. Today's Chinese housing price is also extremely high, and the debt related to the real estate section is also growing to a worrying rate (also somewhat different, debt in US was mortgage debt of home buyers but debt in China is more developer debt and local government debt.). In addition, Chinese government also has strict regulations on the banking industry. Besides these, both two countries consider buying houses as the most profitable and stable investment. However, beside these, there are also differences between them.

From the family and government aspect, regional income inequality is higher in China, so the value of living in first tier city is higher (because best jobs are in few cities). Whereas in US, economic development is more spread, so demand for top cities is not as high as in china. On the other hand, the high demand in china seems to appear more stable than the USA has, since in china, due to the cultural reasons, owning a house is essential to the family formation and marriage qualification. Having more real estate houses can make a man more marriageable. As a result, demand elasticity might be lower in China. But it is still unlikely for the demand of houses to be sustainable if the house prices go down since no one would pay an excess- value mortgage.

Secondly, the Chinese government has more control on the financial system, and it even can force the whole banking system to do interbank lending because they are all state companies. Whereas, in the US, governments and Federal reserves failed to do that.

So, it seems like financial crisis are more likely to happen in, e America. Furthermore, Chinese inflated housing price seems not be a market phenomenon. It looks more like a consequence which government accidentally caused it. The local governments are the beneficiary of the rising house prices. Due to the public ownership of land, government is like a monopoly, it can sell in a relatively high price, especially when the real estate is a good investment option. In the end, they gain lots of profits. e.g., raised land prices--higher house prices--more investment capital--growth of local economy--bonus from central administration (Beijing). When the central administration wants to stop increasing price, it may face some political obstacle in some areas. For example, households may not want to see their houses' price going down and the local governments didn't; want to lose their major fiscal income.In contrast, in America this phenomenon is spontaneous made by investors and financial institutions.

From the city aspect, there is another significant index difference between China and the USA which is urbanization rate. Chinese urbanization is still progressed in a fast rate, while around 2008, the USA's urbanization rate doesn't fluctuate too much. But does this mean that the urbanization rate is a signal that the demand of the houses won't decrease but increase in the short period? The problem is Rural to urban migrants usually do not have enough money to afford houses in first tier cities, so they are not the main source of the high house prices.In other words, the migrants from the rural areas to the city must have the ability to purchase it. Unfortunately, the ration of house to income is about 30 , and this number for the rural workers is even larger, and the urbanization is steered by the government to the third and fourth tier city, which is not as rich as city like Beijing and shanghai. 


\section{Degree of urbanization in China from 1980 to 2020}

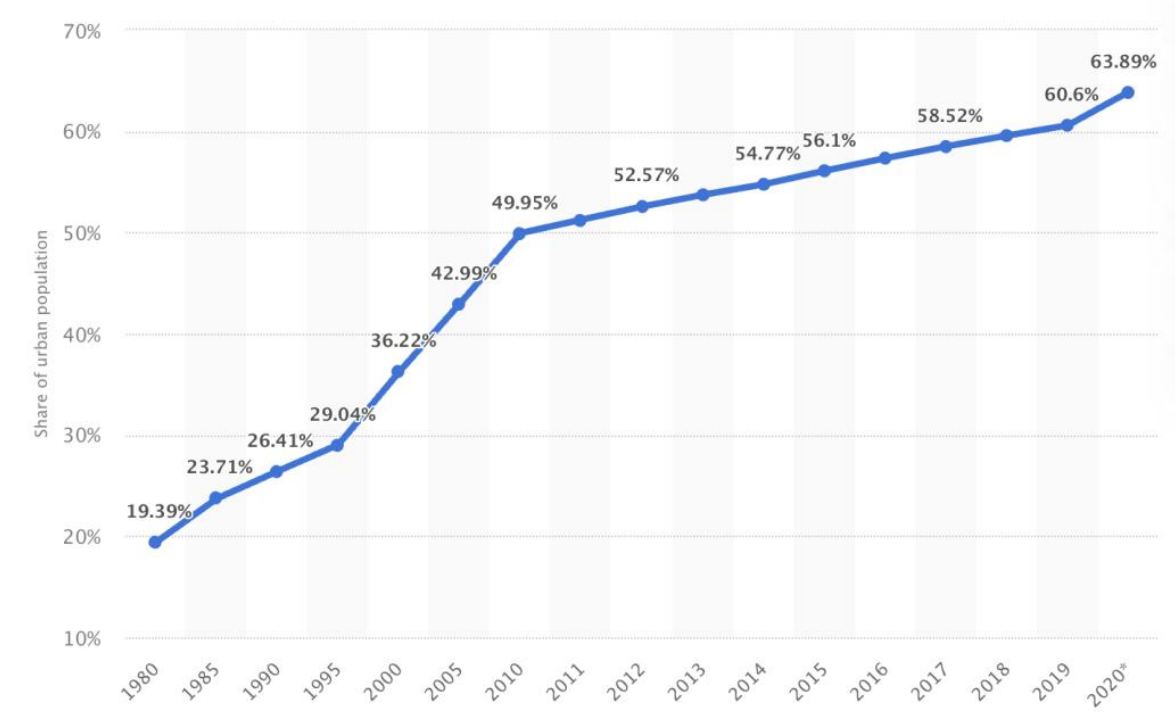

Figure 4. Degree of urbanization in china from 1980 to 2020

Sources: https://www.statista.com/statistics/270162/urbanization-in-china/

\section{Degree of urbanization in the United States from 1970 to 2020}

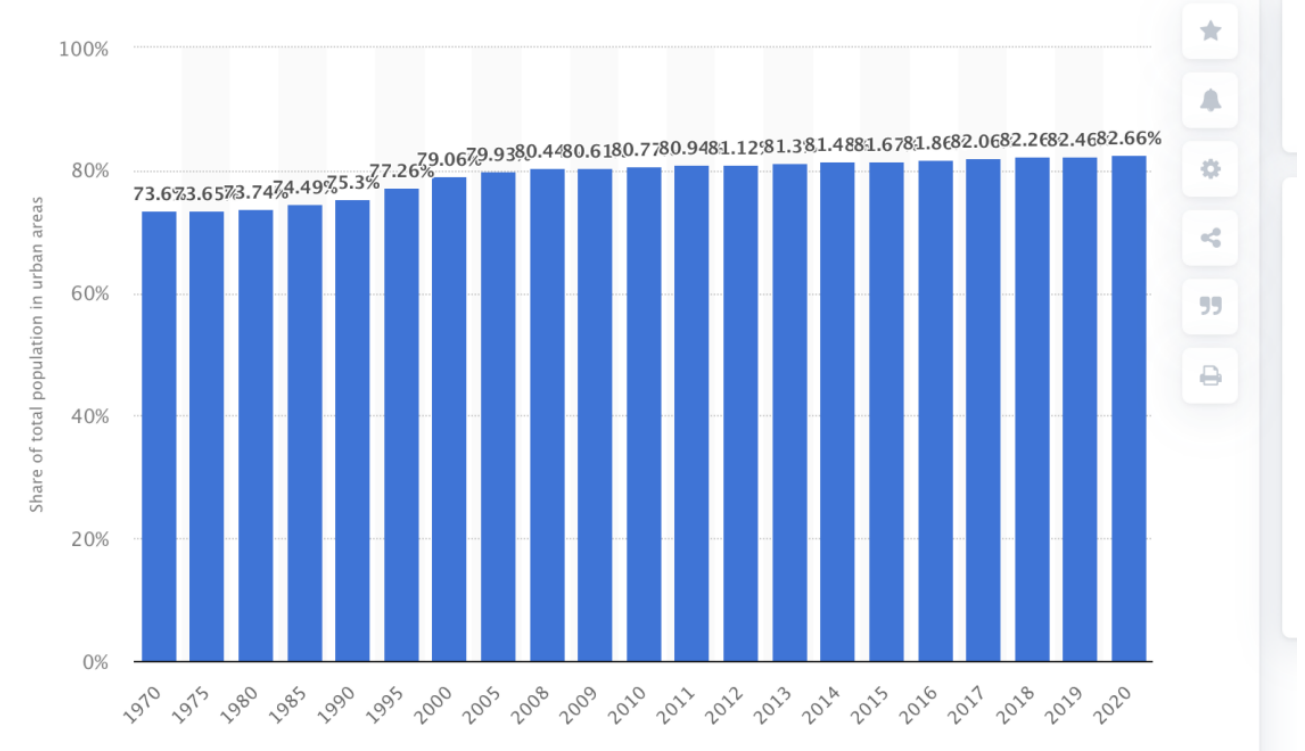

Figure 5. Urbanization rate of America

Source:https://www.statista.com/statistics/269967/urbanization-in-the-united-states/

From the financial aspect, the USA's financial market is highly complex and the policy in 2008 was dominant by financial liberalization theory. High leverage ratio is not uncommon. However, the Chinese government, in recent years, are attempting to achieve financial deleveraging, and put more restrictions on financial innovations, but there are still many debts with real estate section. The mortgage' quality in china now may be higher than the USA before the crisis, since, till now, if anyone wants to borrow money from Chinese banks, he must follow a lot of procedures like offering the proof of income. However, the loans to developers are still likely to default. Recently the real estate industry leader of China, Evergrande ,is facing a serious debt problem. Thus, the default of loans will still be a primary concern of Chinese governments. 
In conclusion, the key point of whether it will happen a financial crisis in China is the price. But the strategy of Chinese government is very hard to achieve, it doesn't want the price of the houses to go down or go up. In contrast, it wants the price of the houses to be unchanged and this apparently disobeys the law of the market, especially when the market price appears the trend to go down. The unchanged policy made by some local governments would hurt the developer companies. Of course, they have reasons to do that. The government has relied on selling lands to get fiscal income for a long time and even they do this, it still accumulates a lot of deficit. If the price of the houses goes down, its fiscal income also shrinks and it may face a worse debt problem. In the end, although the mortgage is less likely to fail, the demand of houses is more elastic, Chinese governments has more control on the financial system, and there are more migrants from the rural areas, it is still possible for the financial crisis happen.

\section{References}

[1] Jarvis, J. (Director). (2012). Crisis of Credit [Motion Picture]. Retrieved from http://crisisofcredit.com/.

[2] KAGAN, J. (2021, 8 15). Mortgage-Backed Security (MBS). Retrieved from Investopedia: https:// www. investopedia.com/terms $/ \mathrm{m} / \mathrm{mbs}$.asp.

[3] TARDI, C. (2021, May 20). Collateralized Debt Obligation (CDO). Retrieved from Investopedia: https:// www. investopedia.com/terms/c/cdo.asp. 